\title{
Breast Cancer pT1a TNM Finding v6 and v7
}

National Cancer Institute

\section{Source}

National Cancer Institute. Breast Cancer pT 1a TNM Finding v6 and v7. NCI Thesaurus. Code C48980.

Breast cancer with tumor size more than $0.1 \mathrm{~cm}$, but not more than $0.5 \mathrm{~cm}$ in greatest dimension. (from AJCC 6th and 7th Eds.) 